\title{
Tumor-Infiltrating Lymphocytes in Breast Carcinoma: Immunohistochemical Analysis
}

\author{
Dr. Amol R. Rajhans ${ }^{* 1}$, MD, Dr. Deepak S. Howale ${ }^{2}$ \\ ${ }^{1}$ Pathology, DCP Consultant Pathologist Shashwat Hospitals, Pune \\ ${ }^{2}$ Dean Govt. Medical College, Silvassa
}

\begin{abstract}
Breast cancer is the most common invasive cancer in women, and the second main cause of cancer death in women, after lung cancer. Breast cancer is cancer that develops from breast tissue. Signs of breast cancer may include a lump in the breast, a change in breast shape, dimpling of the skin, fluid coming from the nipple, a newly inverted nipple, or a red or scaly patch of skin. In those with distant spread of the disease, there may be bone pain, swollen lymph nodes, shortness of breath, or yellow skin.In 2017, around 252, 710 new diagnoses of breast cancer are expected in women, and around 40,610 women are likely to die from the disease. Awareness of the symptoms and the need for screening are important ways of reducing the risk. Material and Methods: This retrospective study was carried out in the department of Pathology, Shashwat Hospitals, Pune, a total of 38 retrospective breast carcinoma tissues were obtained from female patients. Representative paraffin blocks and haematoxylin and eosin (HandE)-stained sections were retrieved from the pathology department. The patients' records were reviewed to look for the patient age and the clinical stage of the disease. The stage of the cancer was reported according to the American Joint Committee of Cancer. As tissue and patient data was collected in an anonymous way no written or informed consent was required for the study purpose. Results and Observations: According to data by clinical staging Stage I, Stage II, Stage III and Stage IV were 16 (42.11\%), 11(28.95\%), 7 $(18.42 \%)$ and $4(10.53 \%)$ respectively. According to histology Stage I, Stage II, Stage III and Stage IV were 2 (5.26\%), 11(28.95\%), 24 $(63.16 \%)$ and $1(2.63 \%)$ respectively. Hand E-stained sections showed that tumour-infiltrating lymphocytes (TILs) were present in 31 of the 38 carcinomas $(81.58 \%)$. Majority of theTILs were T lymphocytes and was present in all 31 cases. CD4+ cells were seen 31 patients and CD $8+$ were seen in 25 cases. B cells were seen in 21 cases. TILs were analysed according to the clinical stage of breast cancer, stages III and IV tumors showed significantly higher densities of total lymphocytes, T lymphocytes, and CD4+ lymphocytes as compared to stage II tumors. Lymphocyte immuno phenotypes and the total TILs also showed a high significantly positive correlation between each lymphocyte population/subpopulation and the total TILs. Conclusion: $\mathrm{T}$ and B lymphocytes were expressed in breast carcinoma with High prevalence of T lymphocytes CD4+ cells. However larger no of cases are required to confirm the findings and extensive large studies are required.
\end{abstract}

\section{Introduction}

The interplay between the immune system and cancer cells is critical for tumor progression. ${ }^{[2]}$ But there is a complex interaction between immune cells and cancer. Recent evidences suggested that there is an association between lymphocytic infiltration and improved neo-adjuvant chemotherapy response. ${ }^{[3]}$ It has been suggested that the cell death (apoptosis) triggers an immune system response, and certain types of chemotherapies may enhance cytotoxic lymphocyte responses and confer permanent anti-tumor immunity. ${ }^{[4]}$ Tumor-infiltrating lymphocytes (TILs) have been recognized in breast cancer and It has been suggested that the presence of TILs is an indication of favourable prognosis. ${ }^{[5,6]} \mathrm{In}$ 2017, around 252, 710 new diagnoses of breast cancer are expected in women, and around 40,610 women are likely to die from the disease. Awareness of the symptoms and the need for screening are important ways of reducing the risk

Two hypothesis has been projected for the role of TIL: lymphocytic infiltrate merely reflects nonspecific inflammatory reaction resulting from tumor-derived chemokines and cytokines, and the other is that they represent a specific immunologic reaction. ${ }^{[7]}$

Breast cancer is the most common malignant disorder in women. ${ }^{[8]}$ The diversity of tumors affecting the breast is being increasingly reflected in the diversification of therapeutic approaches that are based on appropriate biomarkers but there is always a need of additional biomarkers for therapy, including administration of chemotherapeutic agents. The presence of tumor-infiltrating lymphocytes (TILs) has been recognized as a biomarker of antitumor immune response across a wide range of tumors. The presence of TILs has been associated with improved prognosis in many of the cancers. ${ }^{[9]}$ In one of the study shown an association between the expression of the chemokine CXCL10, its receptor CXCR3 and lymphocytic infiltrate that included CD4+, CD8+ and regulatory T-lymphocytes expressing fork head box P3 protein (FOXP3). ${ }^{[10]}$

In breast cancer an association between blood vessels with High endothelial venules (HEV) phenotype and lymphocytic infiltration has also been observed. ${ }^{[11]}$

Many of the methods currently used to detect TILs in tumour tissues are based on immunohistochemistry. In this approach paraffin-embedded tumour specimens are used, and may be utilized in retrospective analyses on archival samples. Also monoclonal antibodies are usually used to detect different lymphocyte populations.

Thus TILs is an important predictive and prognostic biomarker in patients with breast cancer and the assessment of TILs is based on 


\section{International Journal of Innovative Research in Medical Science (IJIRMS) Volume 03 Issue 12 Dec 2018, ISSN: 2455-8737, Imp. Factor - 4.102 \\ Available online at - www.ijirms.in}

routine immunohistochemical demonstration of several lymphocytic surface antigens and may, therefore, be performed in any routine pathological laboratory.

\section{Material and Methods}

This retrospective study was carried out in the department of Pathology, Shashwat Hospitals, Pune, a total of 38 retrospective breast carcinoma tissues were obtained from female patients. Representative paraffin blocks and haematoxylin and eosin (HandE)-stained sections were retrieved from the pathology department. The patients' records were reviewed to look for the patient age and the clinical stage of the disease. The stage of the cancer was reported according to the American Joint Committee of Cancer. ${ }^{[12]}$ As tissue and patient data was collected in an anonymous way no written or informed consent was required for the study purpose.

Histopathology examination of all 38 tissue sections was done. Also examinations of 25 benign tissues were done for comparison. Histological grading of tumors according to Bloom and Richardson was done ${ }^{[13]}$ and classified as invasive duct carcinoma (NOS) into grade 1 (well differentiated), grade 2 (moderately differentiated), and grade 3 (poorly differentiated). Histologic sections of both carcinoma cases and benign breast lesions were examined for the density of TILs. Paraffin-embedded and formalin fixed tissue sections from the 38 mammary carcinomas stained for CD3+ (Tlymphocyte marker), CD4+ (helper/inducer T-lymphocyte marker), CD8+ (suppressor/cytotoxic T-lymphocyte marker), and CD20+ (B-lymphocyte marker). Antibodies used were monoclonal antibodies. Positive and negative controls were used in parallel.

TILs were evaluated in $\mathrm{H} \& \mathrm{E}$-staining and immunostained tissue sections for both mammary carcinomas pathologists. The density of the total lymphocytic infiltrate in $\mathrm{H}$ \& E-stained sections and the density of each cell immunophenotype in the immunostained slides was semi-quantitatively graded depending upon the aggregates of the lymphocytes they were classified in to intermediate and extensivegroup.

Statistical analysis was analyzed with SPSS for Windows. The frequencies of the various types of TILs in breast carcinomas and benign lesions were compared by means of Fisher's exact test. Chisquare test was applied. Correlations between the density of the total TILs and each of the lymphocyte subsets were determined. The level of significance was set at $<0.05$.

\section{Results}

Table 1: Histological and clinical staging of mammary carcinoma

\begin{tabular}{|l|c|c|c|c|}
\hline & $\begin{array}{c}\text { Clinical } \\
\text { staging }\end{array}$ & $\boldsymbol{\%}$ & $\begin{array}{c}\text { Histological } \\
\text { staging }\end{array}$ & $\boldsymbol{\%}$ \\
\hline Stage I & 16 & 42.11 & 2 & 5.26 \\
\hline Stage II & 11 & 28.95 & 11 & 28.95 \\
\hline Stage III & 7 & 18.42 & 24 & 63.16 \\
\hline Stage IV & 4 & 10.53 & 1 & 2.63 \\
\hline Total & 38 & 100 & 38 & 100 \\
\hline
\end{tabular}

According to data by clinical staging Stage I, Stage II, Stage III and Stage IV were $16(42.11 \%), 11(28.95 \%), 7(18.42 \%)$ and 4 (10.53\%) respectively. According to histology Stage I, Stage II,
Stage III and Stage IV were 2 (5.26\%), 11(28.95\%), 24 (63.16\%) and $1(2.63 \%)$ respectively.

Hand E-stained sections showed that tumour-infiltrating lymphocytes (TILs) were present in 31 of the 38 carcinomas $(81.58 \%)$. Majority of theTILs were $\mathrm{T}$ lymphocytes and was present in all 31 cases. CD4+ cells were seen 31 patients and CD $8+$ were seen in 25 cases. B cells were seen in 21 cases

Frequency of TIL in carcinoma and in benign tumors were compared.

Table 2: Tumour-infiltrating lymphocytes in breast carcinomas $(n=38)$ and benign proliferative breast lesions $(n=25)$

\begin{tabular}{|l|c|c|c|c|c|}
\hline \multirow{2}{*}{ Lymphocytes } & \multicolumn{2}{|c|}{ Breast Cancer } & \multicolumn{2}{c|}{ Benign } & P value \\
\cline { 2 - 5 } & Present & Absent & Present & Absent & P \\
\hline Total & 31 & 7 & 5 & 20 & $<0.001$ \\
\hline T cells & 31 & 7 & 5 & 20 & $<0.001$ \\
\hline CD4+ cells & 31 & 7 & 5 & 20 & $<0.001$ \\
\hline CD8+ cells & 13 & 25 & 3 & 22 & $<0.001$ \\
\hline B cells & 21 & 17 & 23 & 2 & $<0.001$ \\
\hline
\end{tabular}

TILs were analysed according to the clinical stage of breast cancer, stages III and IV tumors showed significantly higher densities of total lymphocytes, T lymphocytes, and CD4+ lymphocytes as compared to stage II tumors.

Lymphocyte immuno phenotypes and the total TILs also showed a high significantly positive correlation between each lymphocyte population/subpopulation and the total TILs.

\section{Discussion}

Infiltration of anti-tumor type 1 lymphocytes has shown improved prognosis in many different tumor. ${ }^{[14]}$ Besides quantity of lymphocytes, phenotype of that infiltrate determine clinical outcome. Type $1 \mathrm{~T}$-cells have shown association with favourable prognosis. CD4+ T-helper 1 (Th1) cells shown to facilitate antigen presentation through cytokine secretion and activation of antigen presenting cells and CD8+ cytotoxic T-cells (CTL) are essential for tumor destruction ${ }^{[15]}$ In invasive breast cancer, the greatest clinical benefit is seen in tumors with $>50 \%$ lymphocytic infiltrate. ${ }^{[16]}$ Increased CD8+ T-cells have also been shown for improved clinical outcome, and higher intratumoral CD8+ T-cell infiltrate associated with improved breast cancer specific survival. ${ }^{[17]}$

In our study it has been noted that the breast carcinomas had a significantly higher frequency of TILs and their subsets than benign lesions of breast nad this finding was in consistant with other studies. ${ }^{[18,19]}$ This may be due to breast cancer cells which produce cytokines which recruit more lymphocytes. ${ }^{[20]}$

In immunophenotyping it was observed that CD4+ cells were more predominant than the CD8+ cells. This finding was in accordance with the study by Chin Y et al (1992). ${ }^{[21]}$ A study showed therole of $\mathrm{CD} 4$ cells in breast cancer thatextensive lymphocytic infiltration of breast cancer has been linked to increased CD4+ Th1 and Tfh populations, and is associated with better survival. ${ }^{[22]}$ While in another study by Sheu BCet al. CD8+ cells were more predominant than $\mathrm{CD} 4+$ cells. ${ }^{[23]}$ Some studies have also shown prognostic or 


\section{International Journal of Innovative Research in Medical Science (IJIRMS) Volume 03 Issue 12 Dec 2018, ISSN: 2455-8737, Imp. Factor - 4.102 Available online at - $\underline{w w w . j j i r m s . i n}$}

predictive relevance of individual immune cell subpopulations, with High CD3, CD20. ${ }^{[24]}$

In our study TILs were shown in $81.5 \%$ of the breast cancers .same results were shown by Marsigliante et al in his study. ${ }^{[25]}$ The composition and magnitude of the tumor immune infiltrate affects clinical outcome and it hs been demonstrated that breast cancer is an immunogenic tumor and incremental increases in TILs both in and surrounding the tumor have shown to predict both response to chemotherapy and improved survival in patients. ${ }^{[26]}$

In our study $\mathrm{T}$ lymphocytes and $\mathrm{T}$-cell subpopulations were significantly associated with higher histologic grades and in comparison to T lymphocytes and their subsets, B lymphocytes had no significant association

\section{Conclusion}

In our study $\mathrm{T}$ and $\mathrm{B}$ lymphocytes were expressed in breast carcinoma with High prevalence of T lymphocytes CD4+ cells. However larger no of cases are required to confirm the findings and extensive largestudies are required.

\section{References}

[1] Edge B, Brgrd DR, Coducci MA, Compton CC, editors. AJCC cancer staging manual. 7 th ed. New York, NY: Springer;2009.

[2] Senovilla L, Vitale I, Martins I, Tailler M, et. Ai. An immunosurveillance mechanism controls cancer cell ploidy.Science. 2012 Sep 28; 337(6102):1678-84.

[3] Calabrò A, Beissbarth T, Kuner R, Stojanov M, Benner A, Asslaber M, Ploner F, Zatloukal K, Samonigg H, Poustka A, SültmannH.Effects of infiltrating lymphocytes and estrogen receptor on gene expression and prognosis in breast cancer.Breast Cancer Res Treat. 2009 Jul; 116(1):69-77.

[4] Casares N, Pequignot MO, Tesniere A, Ghiringhelli F, Roux S, Chaput N, Schmitt E, Hamai A, Hervas-Stubbs S, Obeid M, Coutant F, Métivier D, Pichard E, Aucouturier P, Pierron G, Garrido C, Zitvogel L, Kroemer G. Caspase-dependent immunogenicity of doxorubicin-induced tumor cell death.JExp Med. 2005 Dec 19; 202(12):1691-701.

[5] Black MM, Barclay TH, Hankey BF. Prognosis in breast cancer utilizing histologic characteristics of the primary tumor. Cancer 1975;36:2048-55.

[6] Mooe OS, Foote FW Jr. The relatively favorable prognosis of medullary carcinoma of the breast. Cancer 1949;2:635-42.

[7] Ben-Hur H, Cohen O, Schneider D. The role of lymphocytes and macrophages in human breast tumorigenesis: An immunohistochemical and morphometric study. Anticancer Res 2002;22:1231-8.

[8] DeSantis C, Ma J, Bryan L, Jemal A: Breast cancer statistics, 2013. CA Cancer J Clin 64: 52-62, 2014

[9] Menard S, Tomasic G, Casalini P, Balsari A, Pilotti S, Cascinelli N, SalvadoriB,Colnaghi MI, Rilke F: Lymphoid infiltration as a prognostic variable for earlyonset breast carcinomas. Clin Cancer Res 3: 817-819, 1997
[10] Mulligan AM, Raitman I, Feeley L, Pinnaduwage D, Nguyen LT, O'Malley FP,Ohashi PS, Andrluis IL: Tumoral lymphocytic infiltration and expression of the chemokine CXCL10 in breast cancer from the Ontario Familial Breast Cancer Registry. Clin Cancer Res 19: 336-346, 2013.

[11] Martinet L, Filleron T, Guellec SL, Rochaix P, Garrido I, Girard J: High endothelial venule blood vessels for tumor-infiltrating lymphocytes are associated with lymphotoxin beta-producing dendritic cells in human breast cancer. J Immunol 191: 2001-2008, 2013

[12] Edge B, Brgrd DR, Coducci MA, Compton CC, editors. AJCC cancer staging manual. 7 th ed. New York, NY: Springer;2009.

[13] Bloom HJ, Richardson WW. Histological grading and prognosis in breast carcinoma. Br J Cancer 1957;11:35977.

[14] Pagès F, Kirilovsky A, Mlecnik B, Asslaber M, Tosolini M, Bindea G, Lagorce C, Wind P, Marliot F, Bruneval P, Zatloukal K, Trajanoski Z, Berger A, Fridman WH, Galon J. In situ cytotoxic and memory $\mathrm{T}$ cells predict outcome in patients with early-stage colorectal cancer.JClinOncol. 2009 Dec 10; 27(35):5944-51

[15] Zitvogel L, Galluzzi L, Kepp O, Smyth MJ, Kroemer G. Type I interferons in anticancer immunity.Nat Rev Immunol. $2015 \mathrm{Jul} ;$ 15(7):405-14.

[16] Denkert C, Loibl S, Noske A, Roller M, Müller BM, Komor M, Budczies J, Darb-Esfahani S, Kronenwett R, Hanusch C, von Törne C, Weichert W, Engels K, Solbach C, Schrader I, Dietel M, von Minckwitz G. Tumor-associated lymphocytes as an independent predictor of response to neoadjuvant chemotherapy in breast cancer.JClinOncol. 2010 Jan 1; 28(1):105-13

[17] Mahmoud SM, Paish EC, Powe DG, Macmillan RD, Grainge MJ, Lee AH, Ellis IO, Green AR. Tumorinfiltrating CD8+ lymphocytes predict clinical outcome in breast cancer.JClinOncol. 2011 May 20; 29(15):194955.

[18] Hussein MR, Hassan HI. Analysis of the mononuclear inflammatory cell infiltrate in the normal breast, benign proliferative breast disease, in situ and infiltrating ductal breast carcinomas: Preliminary observations. J ClinPathol 2006; 59:972-7.

[19] Ben-Hur H, Cohen O, Schneider D. The role of lymphocytes and macrophages in human breast tumorigenesis: An immunohistochemical and morphometric study. Anticancer Res 2002; 22:1231-8.

[20] Camp BJ, Dyhrman ST, Memoli VA, Mott LA, Barth RJ Jr. In situ cytokine production by breast cancer tumorinfiltrating lymphocytes. Ann SurgOncol 1996;3:176-84.

[21] Chin Y, Janseens J, Vandepitte J, Vandenbrande J, Opdebeek L, Raus J. Phenotypic analysis of tumorinfiltrating lymphocytes from human breast cancer. Anticancer Res 1992;12(Suppl 5):1463-6.

[22] Gu-Trantien C, Loi S, Garaud S, Equeter C, Libin M, de Wind A, Ravoet M, Le Buanec H, Sibille C, ManfouoFoutsop G, Veys I, Haibe-Kains B, Singhal SK, Michiels S, Rothé F, Salgado R, Duvillier H, Ignatiadis M, Desmedt C, Bron D, Larsimont D, Piccart M, Sotiriou C, Willard-Gallo K. $\mathrm{CD}^{+}$follicular helper $\mathrm{T}$ cell infiltration predicts breast cancer survival.JClin Invest. $2013 \mathrm{Jul} ; 123(7): 2873-92$. 
[23] Sheu BC, Kuo WH, Chen RJ, Huang SC, Chang KJ, Chow SN. Clinical significance of tumor-infiltrating lymphocytes in neoplastic progression and lymph node metastasis of human breast cancer. Breast 2008; 17(Suppl 6):604-10.

[24] Denkert C, Loibl S, Noske A, Roller M, Müller BM, Komor M, Budczies J, Darb-Esfahani S, Kronenwett R, Hanusch C, von Törne C, Weichert W, Engels K, Solbach C, Schrader I, Dietel M, von Minckwitz G. Tumor-associated lymphocytes as an independent predictor of response to neoadjuvant chemotherapy in breast cancer.JClinOncol. 2010 Jan 1; 28(1):105-13
[25] Marsigliante S, Biscozzo L, Marra A, Nicolardi G, Leo G, Lobreglio GB, et al. Computerized counting of tumour infiltrating lymphocytes in 90 breast cancer specimens. Cancer Lett 1999; 139:33-41.

[26] Adams S, Gray RJ, Demaria S, Goldstein L, Perez EA, Shulman LN, Martino S, Wang M, Jones VE, Saphner TJ, Wolff AC, Wood WC, Davidson NE, Sledge GW, Sparano JA, Badve SS. Prognostic value of tumorinfiltrating lymphocytes in triple-negative breast cancers from two phase III randomized adjuvant breast cancer trials: ECOG 2197 and ECOG 1199.J ClinOncol. 2014 Sep 20; 32(27):2959-66. 